\title{
Consumption of Coconut Oil (Cocos Nucifera ) on Sperm Parameters of Adult Albino Wistar Rats
}

\author{
Victor A. Fischer Christie E. Fischer* Christabel Francis \\ Department of Anatomical Sciences, Faculty of Basic Medical Sciences, University of Calabar, Calabar, Nigeria
}

\begin{abstract}
This study was aimed at assessing the possible effects coconut oil could have on the sperm parameters of albino rats. Twenty adult male Wistar rats randomly divided into four (4) groups of five rats each were investigated. The control group received normal saline and experimental groups; Low Dose (LD), Moderate Dose (MD) and High Dose (HD) received coconut oil extract of $0.5 \mathrm{ml} / \mathrm{kg} \mathrm{b.w}, 1.1 \mathrm{ml} / \mathrm{kg} \mathrm{b.w}$ and $2.2 \mathrm{ml} / \mathrm{kg} \mathrm{b.w} \mathrm{respectively} \mathrm{for}$ fourteen days via orogastric tube. On day 14 of the experiment, the rats were euthanized under chloroform vapour and sacrificed and testes excised. There was an insignificant decrease $(p<0.05)$ in mean testicular weight of the treated rats; LD (1.14 \pm 0.05$)$, MD (1.16 \pm 0.05$)$ and HD $(1.12 \pm 0.06)$ groups compared to the control rats $(1.20 \pm 0.04)$. Sperm count was increased significantly $(\mathrm{p}<0.05)$ in the animals administered with coconut oil; LD $\left(39.72 \pm 0.28 \times 10^{6} / \mathrm{ml}\right), \mathrm{MD}\left(46.76 \pm 1.46 \times 10^{6} / \mathrm{ml}\right), \mathrm{HD}\left(68.18 \pm 0.39 \times 10^{6} / \mathrm{ml}\right)$ in comparison with animals in the control group $\left(35.28 \pm 0.34 \times 10^{6} / \mathrm{ml}\right)$. Sperm motility increased significantly $(\mathrm{p}<0.05)$ in animals of the HD group $(55.00 \pm 1.58 \%)$ compared to what was observed in rats found in LD $(37.60 \pm 0.81 \%)$ and MD groups $(45.00 \pm 0.84 \%)$. The HD group recorded $(85.00 \pm 0.71 \%)$ sperm viability, a significant increase $(p<0.05)$ compared to that of the control group $(75.60 \pm 0.93 \%)$. Sperms with normal morphology were significantly increased $(\mathrm{p}<0.05)$ in LD $(75.60 \pm 0.68 \%), \mathrm{MD}(76.00 \pm 1.87 \%)$ and HD $(87.20 \pm 0.86 \%)$ compared to the control group $(69.00 \pm 1.22 \%)$. Coconut oil has no deleterious effect on the sperm parameters and can lead to enhanced spermatogenesis.
\end{abstract}

Keywords: Cocos nucifera, sperm parameters, coconut oil

DOI: $10.7176 / \mathrm{JBAH} / 9-14-06$

Publication date:July $31^{\text {st }} 2019$

\section{Introduction}

Coconut (Cocos nucifera) belongs to the family Aracaceae or Palmae and is one of the most commercially grown and used nuts in the world. Historically, coconuts and their extracted oil have served man as important foods for thousands of years (Ghazali et al., 2009). Much of the seed kernel is consumed locally as food, while its oil (coconut oil) is used for cooking, soap making and production of margarine (Ishiaq \& Odeyemi, 2012). The oil plays a great role in skin care, hair care, stress relief, weight loss and cholesterol level maintenance, immunomodulatory effects, cardiovascular uses and more recently in Alzheimer's disease. Other potential benefits include prevention of different biological conditions due to its active polyphenol components (Nevin \& Rajamohan, 2004). Coconut oil is a good source of iron, sodium, potassium and calcium because the concentrations of these elements in the oil meet up with the adequate quantity needed by the body daily. Thus, coconut oil has both nutritional and pharmacological benefits and being free from lead, it is safe for human consumption (Sani et al., 2014). With an increase in the use of coconut oil, the possible effects it could have on fertility can be useful in growing study in fertility research. This article presents the effect of coconut oil on the sperm parameters.

\section{Materials and method}

\subsection{Coconut oil extraction}

The coconut oil was extracted using a modified wet extraction method described by Nevin and Rajamohan $(2004,2006)$. The resultant coconut milk was left for $24 \mathrm{hrs}$ to facilitate the gravitational separation of the emulsion as described by Onsaard et al. (2005) and Nour et al. (2009). Demulsification produced layers of an aqueous phase (water) on the bottom, an emulsion phase (cream) in the middle layer and an oil phase on top as described by Nour et al. (2009). The oil on top was scooped and heated for about $4 \mathrm{hrs}$ to remove moisture. The obtained oil was then filtered through a fine sieve, stored at room temperature and used for the experiment.

\subsection{Experimental design}

Twenty adult male albino Wistar rats with average weight of $150 \mathrm{~g}$ acquired from the University of Calabar Animal Farm were divided into four groups of five rats each. The control group received normal saline and experimental groups; Low Dose (LD), Moderate Dose (MD) and High Dose (HD) received coconut oil extract of $0.5 \mathrm{ml} / \mathrm{kg}$ b.w, $1.1 \mathrm{ml} / \mathrm{kg}$ b.w and $2.2 \mathrm{ml} / \mathrm{kg}$ b.w respectively for fourteen days via orogastric tube. The rats were euthanized under chloroform vapour and sacrificed and testes excised. Testes were then teased with a sterile surgical blade and transferred into $10 \mathrm{ml}$ physiological saline at $37^{\circ} \mathrm{C}$ in a sterile container. The entire preparation 
was shaken and kept in the incubator for 15 minutes then studied under a light microscope

\subsection{Statistical analysis}

The differences between the treated and control groups data was statistically evaluated using ANOVA and SPSS Computer Package since the data were parametric. All data was expressed as mean values \pm SEM with significant values at $\mathrm{p}<0.05$.

\section{Results}

\subsection{Body Weight}

There was significant increase $(\mathrm{p}<0.05)$ in the body weight of rats found in MD group $(92.63 \pm 5.61 \mathrm{~g})$ and the change seen in LD group $(76.50 \pm 14.82 \mathrm{~g})$ was similar to that observed in the HD group $(77.19 \pm 0.05 \mathrm{~g})$ but significantly lower $(\mathrm{p}<0.05)$ compared to the control $(69.10 \pm 0.36 \mathrm{~g})$. (Table 1$)$.

Table 1: Comparison of body weights between the control and experimental groups

\begin{tabular}{cccc}
\hline Experimental Groups & Initial Body weight (g) & Final Body weight (g) & Weight change(g) \\
\hline Control & $180.50 \pm 0.02$ & $249.00 \pm 0.38$ & $69.10 \pm 0.36$ \\
Low dose & $180.54 \pm 0.01$ & $257.04 \pm 14.81$ & $76.50 \pm 14.82$ \\
Moderate dose & $180.47 \pm 0.04$ & $273.10 \pm 5.60^{*}$ & $92.63 \pm 5.61^{*}$ \\
High dose & $180.43 \pm 0.01^{\mathrm{a}}$ & $257.62 \pm 0.06$ & $77.19 \pm 0.05$ \\
\hline
\end{tabular}

Values are expressed as mean \pm SEM, $\mathrm{n}=5$

$*$ = significantly different from control at $\mathrm{p}<0.05$

$\mathrm{a}=$ significantly different from Low dose at $\mathrm{p}<0.05$

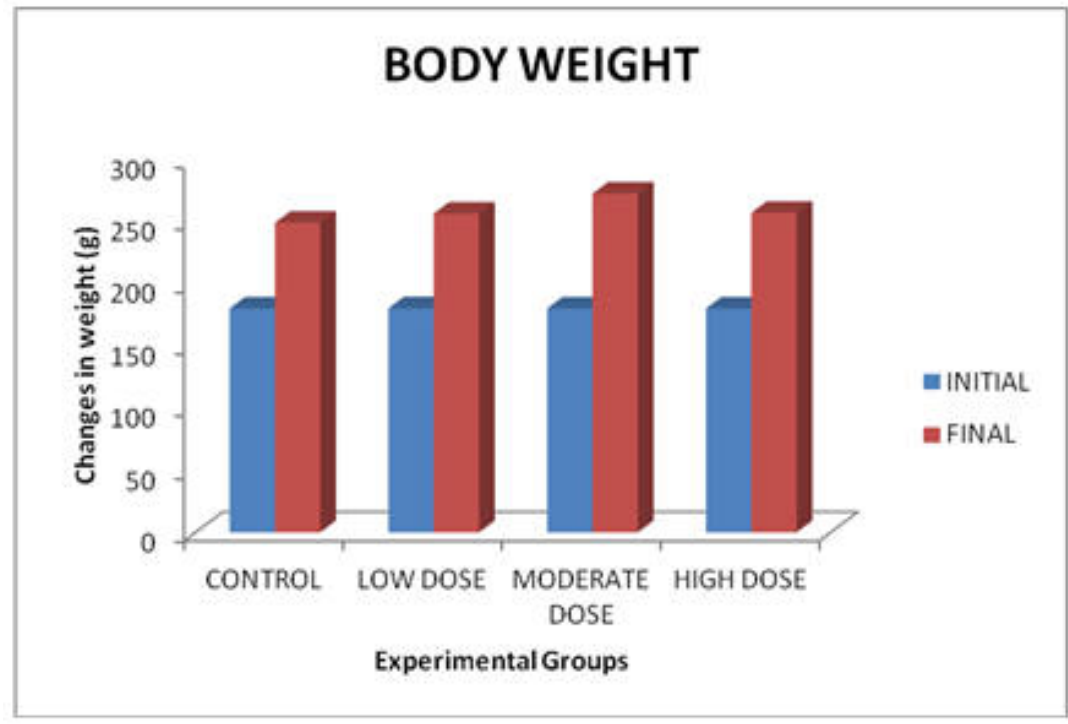

Figure 1: Chart showing the changes in body weight of control and the experimental groups.

\subsection{Testicular Weight}

In this present study, coconut oil caused decrease $(\mathrm{p}<0.05)$ in the testicular weight of treated rats; low dose $(1.14 \pm 0.05)$, moderate dose $(1.16 \pm 0.05)$ and high dose $(1.12 \pm 0.06)$ groups compared to the control rats $(1.20 \pm 0.04)$. The moderate dose group presented a significantly higher $(\mathrm{p}<0.05)$ value compared to the low dose and the high dose groups. (Table 2)

Table 2: Comparison of testicular weights between the control and experimental groups

\begin{tabular}{cc}
\hline Experimental Groups & Testicular weight (g) \\
\hline Control & $1.20 \pm 0.04$ \\
Low dose & $1.14 \pm 0.05$ \\
Moderate dose & $1.16 \pm 0.05$ \\
High dose & $1.12 \pm 0.06$ \\
\hline
\end{tabular}

Values are expressed as mean \pm SEM, $\mathrm{n}=5$ 


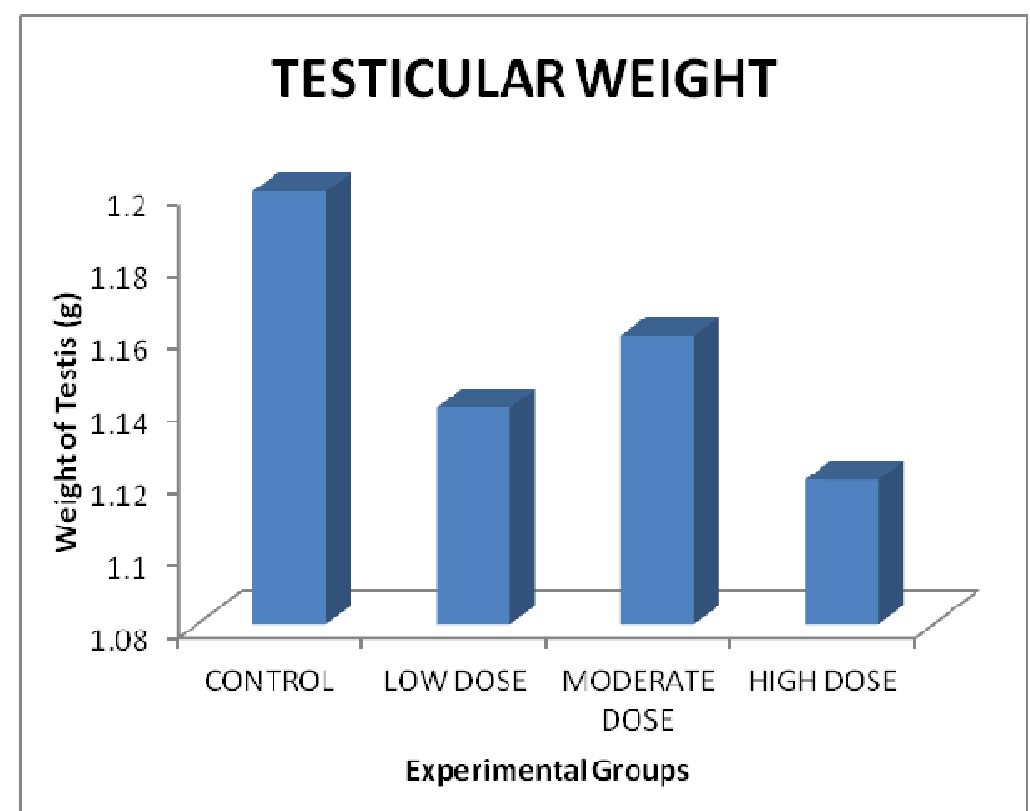

Figure 2: Chart showing testicular weights in the different experimental groups

\subsection{Sperm Parameters}

In Table 3 the sperm motility of rats in high dose group $(55.00 \pm 1.58 \%)$ showed significant increase $(\mathrm{p}<0.05)$ compared to what was observed in rats found in low dose $(37.60 \pm 0.81 \%)$ and moderate dose groups $(45.00 \pm 0.84 \%)$. The mean value of sperm count of rats in the low dose $\left(39.72 \pm 0.28 \times 10^{6} / \mathrm{ml}\right)$, moderate dose $\left(46.76 \pm 1.46 \times 10^{6} / \mathrm{ml}\right)$ and high dose groups $\left(68.18 \pm 0.39 \times 10^{6} / \mathrm{ml}\right)$, were significantly higher $(\mathrm{p}<0.05)$ compared to that of the control $\left(35.28 \pm 0.34 \times 10^{6} / \mathrm{ml}\right)$ as seen in Table 4 . The high dose group $(85.00 \pm 0.71 \%)$ showed significant increase $(\mathrm{p}<0.05)$ in sperm viability compared to that of the low dose $(77.20 \pm 0.58 \%)$ and moderate dose groups $(79.40 \pm 0.60 \%)$. Also, the viable sperm cells in groups treated with coconut oil showed significant increase $(p<0.05)$ compared to that of the control group $(75.60 \pm 0.93 \%)$ (Table 5). In Table 6, Sperms with normal morphology were significantly increased $(\mathrm{p}<0.05)$ in low dose $(75.60 \pm 0.68 \%)$, moderate dose $(76.00 \pm 1.87 \%)$ and high dose $(87.20 \pm 0.86 \%)$ compared to the control group $(69.00 \pm 1.22 \%)$. Also, the high dose group showed significant increase $(\mathrm{p}<0.05)$ in the occurrence of normal morphology when compared to the low dose and moderate dose groups. The percentage of curved body in rats of low dose $(16.40 \pm 0.51 \%)$, moderate dose $(14.60 \pm 1.36 \%)$ and high dose $(4.80 \pm 0.37 \%)$ groups is significantly lower $(\mathrm{p}<0.05)$ than that of the control group $(18.60 \pm 0.98 \%)$. The occurrence of bent head was significantly higher $(\mathrm{p}<0.05)$ in the moderate dose group $(5.20 \pm 1.53 \%)$ while the low dose group $(0.40 \pm 0.24 \%)$ had a similar population of spermatozoa with bent head as the high dose group $(0.40 \pm 0.24 \%)$ which was significantly lower $(\mathrm{p}<0.05)$ when compared with those in the control group $(5.00 \pm 1.53 \%)$. Rats in the low dose group $(7.00 \pm 0.32 \%)$ were observed to have significant increase $(\mathrm{p}<0.05)$ in spermatozoa with bent tail when compared with moderate $(3.60 \pm 1.50 \%)$ and high dose group $(4.80 \pm 0.37 \%)$. Also, those in moderate and high dose groups had significantly lower $(\mathrm{p}<0.05)$ percentage of such sperms when compared with those of the control group $(5.00 \pm 0.71 \%)$. The moderate dose group $(3.60 \pm 0.51 \%)$ showed significant increase $(\mathrm{p}<0.05)$ in the number of spermatozoa with defective head and body compared to low dose $(1.60 \pm 0.51 \%)$ and high dose groups $(2.40 \pm 0.24 \%)$ (Table 6$)$.

TABLE 3: Comparison of sperm motility indices between control and experimental groups

\begin{tabular}{cccccc}
\hline $\begin{array}{c}\text { Experimental } \\
\text { Group }\end{array}$ & $\begin{array}{c}\text { Dosage } \\
\mathbf{m l} / \mathbf{k g b w}\end{array}$ & Motile (\%) & $\begin{array}{c}\text { Actively Motile } \\
\mathbf{( \% )}\end{array}$ & $\begin{array}{c}\text { Sluggishly } \\
\text { Motile (\%) }\end{array}$ & Dead (\%) \\
\hline Control & Nil & $45.00 \pm 1.58$ & $34.00 \pm 1.87$ & $15.00 \pm 15.8$ & $55.00 \pm 1.58$ \\
Low dose & 0.5 & $37.60 \pm 0.81^{*}$ & $25.00 \pm 1.58^{*}$ & $12.60 \pm 0.93$ & $63.00 \pm 1.22^{*}$ \\
Moderate dose & 1.1 & $45.00 \pm 0.84^{\mathrm{a}}$ & $22.00 \pm 2.55^{*}$ & $21.00 \pm 1.87 * \mathrm{a}$ & $55.00 \pm 1.58^{\mathrm{a}}$ \\
High dose & 2.2 & $55.00 \pm 1.58^{* a b}$ & $30.00 \pm 1.58^{\mathrm{a}}$ & $35.00 \pm 1.58^{* a b}$ & $46.00 \pm 2.92^{* a b}$ \\
\hline \multicolumn{6}{c}{ Values are expressed as mean \pm SEM, $\mathrm{n}=5$} \\
& $*$ significantly different from control at $\mathrm{p}<0.05$ \\
& $\mathrm{a}=$ significantly different from LD at $\mathrm{p}<0.05$ \\
$\mathrm{~b}=$ significantly different from MD at $\mathrm{p}<0.05$
\end{tabular}




\section{SPERM MOTILITY}

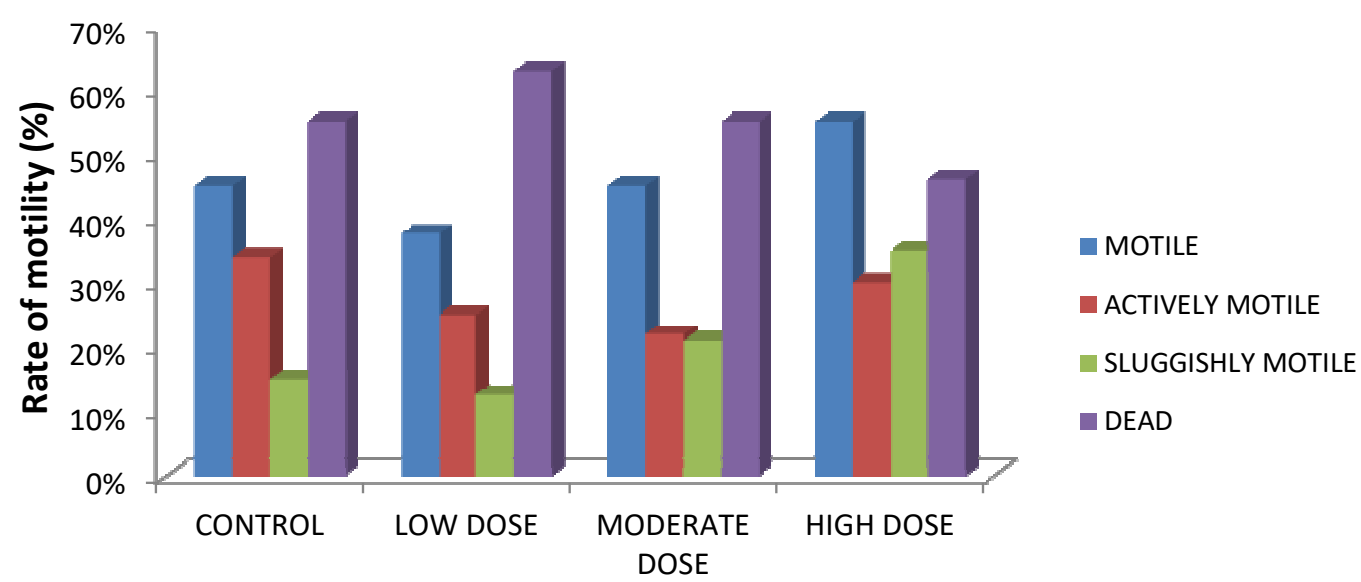

Experimental Groups

Figure. 3: Chart showing sperm motility indices between the control and experimental groups

\begin{tabular}{cc} 
TABLE 4: Comparison of sperm count between control and experimental groups \\
\hline Experimental Group & Sperm Count (x10 $/ \mathbf{m l})$ \\
\hline Control & $35.28 \pm 0.34$ \\
Low dose & $39.72 \pm 0.28^{*}$ \\
Moderate dose & $46.76 \pm 1.46^{* \mathrm{a}}$ \\
High dose & $68.18 \pm 0.39^{* a \mathrm{ab}}$ \\
\hline
\end{tabular}

Values are expressed as mean \pm SEM, $\mathrm{n}=5$

$*$ = significantly different from control at $\mathrm{p}<0.05$

$\mathrm{a}=$ significantly different from $\mathrm{LD}$ at $\mathrm{p}<0.05$

$b=$ significantly different from MD at $p<0.05$

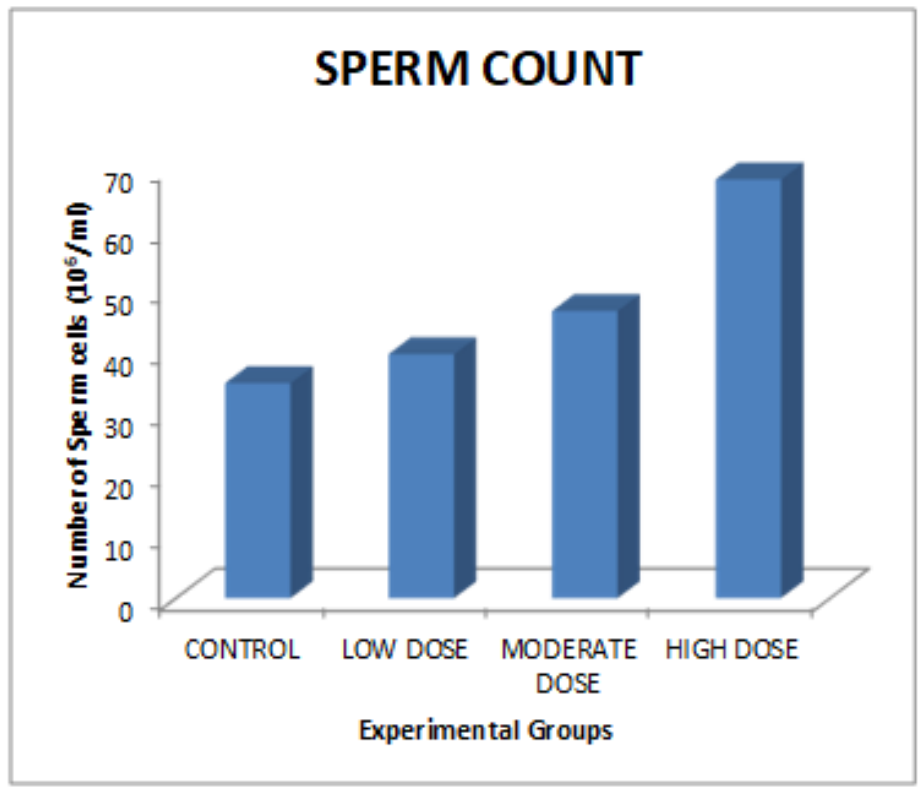

Figure 4: Chart showing sperm count of the control and coconut oil-treated groups. Sperm Viability $=$ Number of viable cells counted/200 x100. 
TABLE 5: Comparison of sperm viability between control and experimental groups

\begin{tabular}{cc}
\hline Experimental Group & Sperm viability (\%) \\
\hline Control & $75.60 \pm 0.93$ \\
Low dose & $77.20 \pm 0.58$ \\
Moderate dose & $79.40 \pm 0.60^{* \mathrm{a}}$ \\
High dose & $85.00 \pm 0.71^{* \mathrm{ab}}$ \\
\hline
\end{tabular}

Values are expressed as mean \pm SEM, $\mathrm{n}=5$

$*=$ significantly different from control at $\mathrm{p}<0.05$

$\mathrm{a}=$ significantly different from $\mathrm{LD}$ at $\mathrm{p}<0.05$

$\mathrm{b}=$ significantly different from $\mathrm{MD}$ at $\mathrm{p}<0.05$

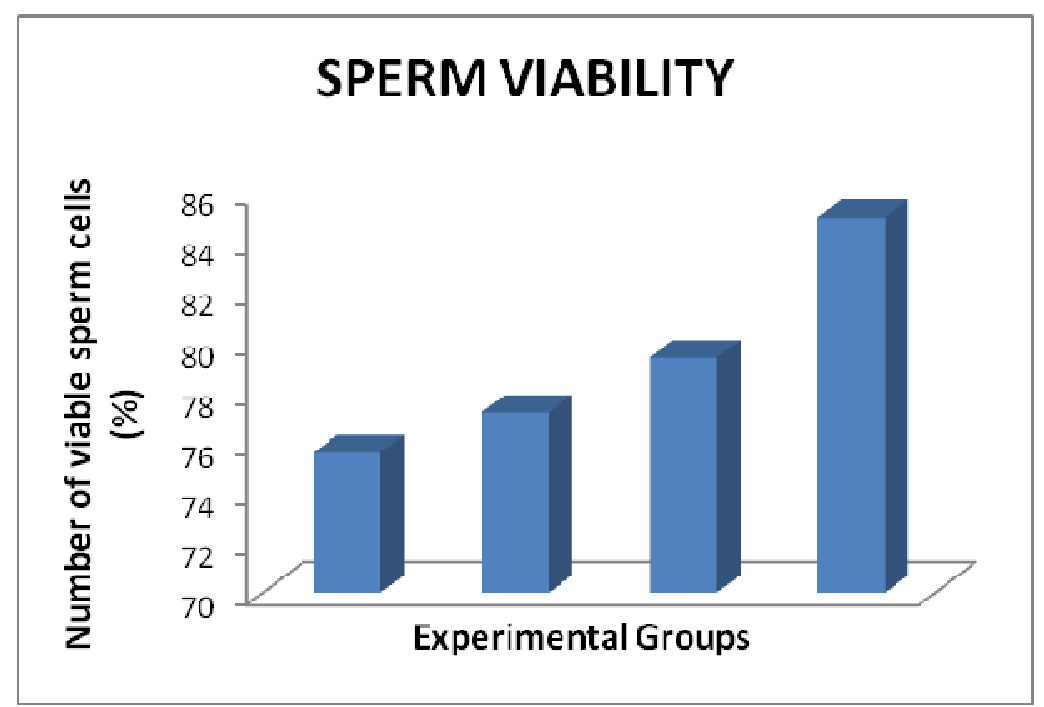

Figure. 5: Chart showing sperm viability of the control and experimental groups.

TABLE 6: Comparison of sperm morphology between the control and experimental groups

\begin{tabular}{|c|c|c|c|c|c|}
\hline $\begin{array}{c}\text { Experimental } \\
\text { Groups }\end{array}$ & $\begin{array}{c}\text { Curved Body } \\
(\%)\end{array}$ & $\begin{array}{c}\text { Bent Head } \\
(\%)\end{array}$ & $\begin{array}{c}\text { Defective Head and } \\
\text { Body }(\%)\end{array}$ & $\begin{array}{c}\text { Bent tail } \\
(\%)\end{array}$ & Normal (\%) \\
\hline Control & $18.60 \pm 0.98$ & $5.00 \pm 0.32$ & $2.60 \pm 0.24$ & $5.00 \pm 0.71$ & $69.00 \pm 1.22$ \\
\hline Low dose & $16.40 \pm 0.51$ & $0.40 \pm 0.24 *$ & $1.60 \pm 0.51$ & $7.00 \pm 0.32$ & $75.60 \pm 0.68 *$ \\
\hline Moderate dose & $14.60 \pm 1.36^{*}$ & $5.20 \pm 1.53^{\mathrm{a}}$ & $3.60 \pm 0.51^{\mathrm{a}}$ & $3.60 \pm 1.50^{\mathrm{a}}$ & $76.00 \pm 1.87^{*}$ \\
\hline High dose & $4.80 \pm 0.37 * a b$ & $0.40 \pm 0.24 * \mathrm{~b}$ & $2.40 \pm 0.24^{\mathrm{b}}$ & $4.80 \pm 0.37$ & $87.20 \pm 0.86^{* a b}$ \\
\hline \multicolumn{6}{|c|}{$\begin{array}{l}\text { Values are expressed as mean } \pm \text { SEM, } \mathrm{n}=5 \\
*=\text { significantly different from control at } \mathrm{p}<0.05 \\
\mathrm{a}=\text { significantly different from LD at } \mathrm{p}<0.05 \\
\mathrm{~b}=\text { significantly different from } \mathrm{MD} \text { at } \mathrm{p}<0.05\end{array}$} \\
\hline
\end{tabular}




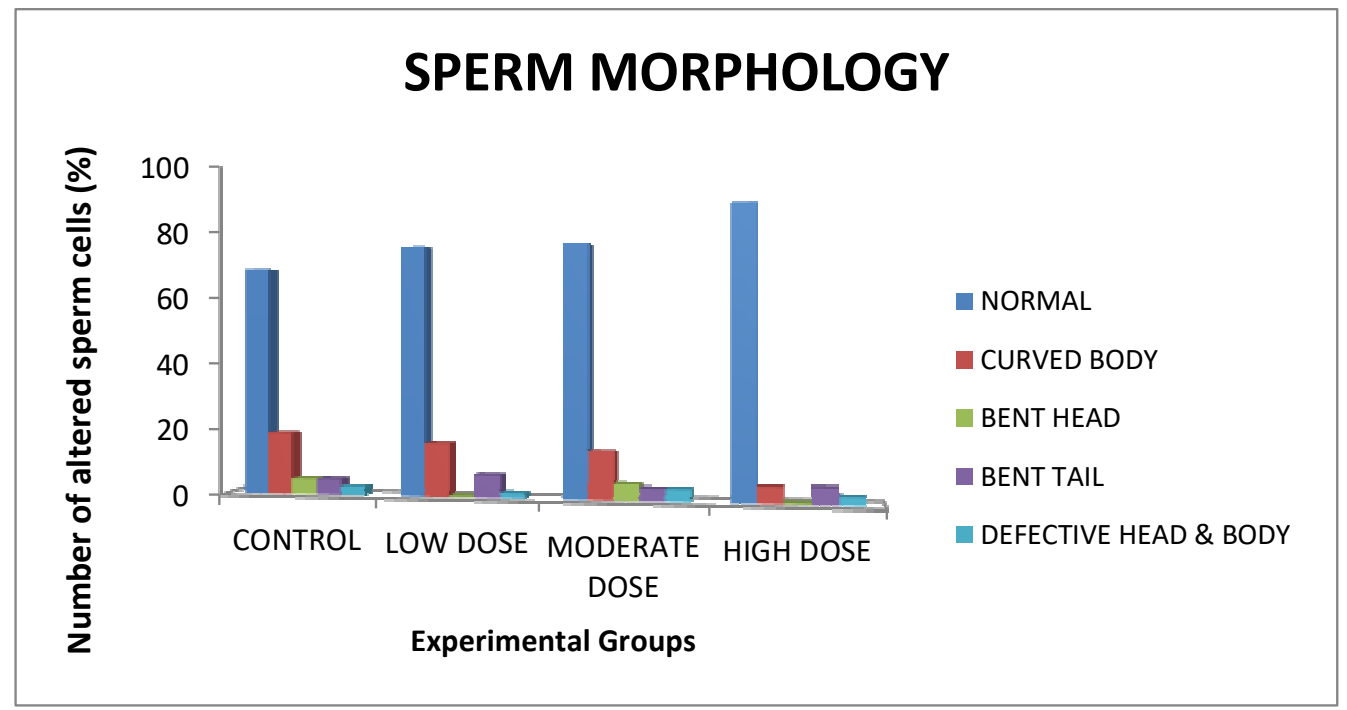

Figure. 6: Chart showing sperm morphology of the control and experimental groups

\section{Discussion}

Results from this research demonstrates that coconut oil extract has no adverse effect on sperm parameters of Wistar rats. It can be seen from this study that the high dose group showed the highest percentage of motility. Coconut oil at HD of $2.2 \mathrm{ml} / \mathrm{kg}$ body weight brought about significant increase $(\mathrm{p}<0.05)$ in the degree of motility of sperm cells compared to the other two groups; (LD and MD). The statistical analysis clearly shows that coconut oil can lead to increase in sperm count significantly $(\mathrm{p}<0.05)$ as seen in the HD group having the highest number of active and live cells compared to the control which is an indication that the extract enhances spermatogenesis. The viable sperm cells in groups treated with coconut oil showed significant increase $(p<0.05)$ compared to that of the control group $(75.60 \pm 0.93 \%)$. In addition, the present study showed that the number of sperms with normal morphology was significantly increased $(p<0.05)$ in the treated group with the highest number being in the HD group compared to the control. The study showed dose dependent increase in percentage of motile sperm, increased sperm count, viability and percentage of normal morphology which is an indication that coconut oil extract could enhance spermatogenesis. Increase in morphologically normal sperms results in increased motility as normal intact sperm is a prerequisite for high speed with straight forward motility. Gandini et al. (2000) postulated that sperm function is strictly correlated with sperm morphology which is a predictor of fertility potential in man. Brucefife (2000) reported that coconut oil has an antioxidant effect. Antioxidants stabilize testicular membranes by decreasing lipid peroxidation and presumably abnormal sperm which will enhance gonadal function (Emanuele and Emanuele, 2001). Eskenazi et al. (2005) also reported higher antioxidant intake is associated with higher sperm numbers and motility which corroborates the results of this research.

\section{Conclusion}

Results from this study indicates that Coconut oil extract has no deleterious effect on the sperm parameters rather improves semen quality and could enhance spermatogenesis.

\section{References}

Brucefife, N. D. (2000). The Miracles of Coconut oil. Health Wise Publications, Piccadilly Books, Limited.

Emanuele, M. A. and Emanuele, A. (2001). Alcohol and the male reproductive system. Alcohol Research and Health, 25:4.

Eskenazi, B., Kidd, S. A., Marks, A.R., Sloter, E.,Block, G.,Wyrobek, A.J (2005) Antioxidant intake is associated with semen quality in Healthy men. Human Reproduction Vol. 20(4) pp. 1006-1012

Ghazali, H. M., Tan, A., Abdulkarim, S. M. \& Dzulkifly, M. H. (2009). Oxidative stability of virgin coconut oil compared with RBD palm olein in deep-fat frying of fish crackers. Journal of Food and Environment, 7(34): $23-27$.

Ishiaq, O. \& Odeyemi, F. (2012). Bio-nutritional constituents of coconut fruit and its possible medicinal applications. African Journal of Plant Science Vol. 6(12), pp. 309-313. http://www.academicjournals.org/AJPS

Maina, M. B., Garba, S. H. \& Jacks, T. W. (2008). Histological evaluation of the rats' testis following 
administration of a herbal tea mixture. J. Pharmacol. Toxicol., 3: 464-470.

Nevin, K. G. \& Rajamohan, T. (2004). Beneficial effects of virgin coconut oil on lipid parameters and in vitro LDL oxidation. Clinical Biochemistry, 37(9): 830-835.

Nevin, K. G. \& Rajamohan, T. (2006). Virgin coconut oil supplemented diet increases the antioxidant status in rats. Food Chemistry, 99(2): 260-266.

Nneli, R. O. \& Woyike, O., A. (2008). Anti-ulcerogenic effects of coconut (Cocos nucifera) extract in rats. Phytother. Res. 22:970-972.

Nour, A. H., Mohammed, F. S., Yunus, R. M., Arman, A. (2009). Demulsification of virgin coconut oil by centrifugation method: A feasibility study. International Journal of Chemical Technology, 1(2): 59-64.

Odenigbo, U. M., \& Otisi, C. A. (2011). Fatty acids and Phytochemical content of different coconut seed flesh in Nigeria. International Journal of Plant Physiology and Biochemistry Vol. 3(11), pp. 176-182. http://www.academicjournals.org/IJPPB

Olayemi, F. O. (2010). A review on some causes of male infertility. African Journal of Biotechnology. Vol. 9(20), pp. 2834-2842. DOI: 10.5897/AJB09.1996 http://www.academicjournals.org/AJB.

Onsaard, E., Vittayanont, M., Srigam, S. \& McClements, D. J. (2005). Properties and stability of oil-in-water emulsions stabilized by coconut skim milk proteins. Journal of Agriculture and Food Chemistry, 53: 57475753.

Sani, I., Owoade, C., Abdulhamid, A., Isah, M., Bello, F., (2014). Evaluation of Physicochemical Properties, Phytochemicals and Mineral Composition of Cocosnuciferal. (Coconut) Kernel Oil.

Swierzewski, S. J. (2009). Male Infertility. www.urologychannel.com/male infertility/index/html.

Thomas, M. J \& Thomas, J. A. (2001). Toxic responses of the reproductive system. In: Casarett \& Doull's Toxicology- The basic science of poisons (6th ed.), McGraw-Hill Medical Publishing Division, New York, pp. 677-681. 